\title{
THE HEARLAB CORTICAL TONE EVALUATION (CTE) PROTOCOL: A CLINICAL FEASIBILITY STUDY
}

\author{
Ahmad A. Alanazi ${ }^{1,2,3}$, Nannette Nicholson ${ }^{1,2}$, Samuel R. Atcherson ${ }^{1,2}$, Patti Martin ${ }^{4}$ \\ ${ }^{1}$ Department of Audiology and Speech Pathology, University of Arkansas for Medical Sciences, Little Rock, AR, \\ USA \\ ${ }^{2}$ Department of Audiology and Speech Pathology, University of Arkansas at Little Rock, Little Rock, AR, USA \\ ${ }^{3}$ Department of Audiology and Speech Pathology, King Saud bin Abdulaziz University for Health Sciences, \\ Riyadh, Saudi Arabia \\ ${ }^{4}$ Department of Audiology and Speech Pathology, Arkansas Children's Hospital, Little Rock, AR, USA \\ Corresponding author: Ahmad A. Alanazi, Department of Audiology and Speech Pathology, University of \\ Arkansas at Little Rock, 2801 South University Ave., Little Rock, AR 72204, USA, e-mail: aalanazi@uams.edu
}

\begin{abstract}
Background: Cortical auditory evoked potentials (CAEPs) have been shown to demonstrate high correlations with pure-tone behavioral thresholds when using research protocols. However, experience using the HEARLab cortical tone evaluation (CTE) procedure clinically in sites independent of the National Acoustic Laboratories (NAL) remains limited. This study aimed to assess the clinical feasibility of the CTE protocol using the HEARLab system to estimate pure-tone behavioral thresholds at 500, 1000, 2000, and $4000 \mathrm{~Hz}$
\end{abstract}

\begin{abstract}
Material and methods: This is a preliminary prospective study designed to compare behavioral hearing thresholds with air conduction CTE of 12 adults (8 with normal hearing and 4 with sensorineural hearing loss). A cortical auditory evoked potential (CAEP) threshold protocol was modeled after an existing auditory brainstem response (ABR) protocol used in-house. A $t$-test was used to identify differences between pure-tone behavioral thresholds and CTE thresholds.
\end{abstract}

Results: Depending on frequency and intensity, CTEs varied from pure-tone behavioral thresholds by as much as $11.2 \mathrm{~dB}$. The average test time to obtain CTEs at four frequencies per ear for 12 participants was 50.85 minutes $(\mathrm{SD}=12.0)$. Implications for inter-test reliability of the CTE protocol are discussed.

Conclusions: The HEARLab CTE protocol is feasible for predicting pure-tone behavioral thresholds in those with normal hearing or with hearing loss. The CTE procedure is a useful alternative tool when behavioral threshold testing is neither possible nor practical.

Key words: hearing loss • hearing threshold • CAEPs • HEARLab • CTE

\section{PROTOCOLO HEARLAB CORTICAL TONE EVALUATION (CTE): ESTUDIO DE LA UTILIDAD CLÍNICA}

\section{Resumen}

Introducción: En los protocolos de ensayos se observa una gran correlación de los potenciales auditivos corticales con los umbrales de la audiometría tonal. Sin embargo, excepto los centros dependientes de National Acoustic Laboratories, se puede observar una limitada práctica de uso del sistema HEARLab, que utiliza la valoración mediante el procedimiento de evaluación del tono cortical (CTE). En este trabajo se ha presentado la posibilidad de una aplicación clínica del protocolo CTE con el uso del sistema HEARLab para estimar los umbrales de la audiometría tonal para las frecuencias 500, 1000, 2000 y $4000 \mathrm{~Hz}$.

Material y métodos: En este estudio preliminar de carácter prospectivo se han comparado los umbrales de la audiometría tonal con los umbrales de conducción aérea medida con el método CTE en 12 adultos (8 de ellos con audición correcta y 4 con hipoacusia perceptiva). El protocolo de valoración de umbral de los potenciales corticales auditivos ha sido elaborado en base al protocolo para la evaluación de la respuesta auditiva del tronco cerebral (ABR). A continuación se realizó la prueba t-Student con el objetivo de identificar las diferencias entre los umbrales obtenidos en la prueba de comportamiento (behavioral) y el CTE.

Resultados: Los umbrales de CTE diferenciaban de los umbrales de audiometría tonal como máximo por 11,2 dB. El promedio de tiempo de ejecución del ensayo para cada uno de los oídos en todos los 12 participantes del estudio ha sido de 50,85 minutos $(\mathrm{SD}=12.0)$. También se han analizado las conclusiones del carácter repetitivo de los resultados entre las pruebas para el protocolo CTE. 
Conclusiones: El protocolo CTE permite estimar los umbrales de la audiometría tonal tanto en personas con audición correcta, como y en personas con la hipoacusia perceptiva. El Protocolo CTE es una alternativa para la audiometría tonal cuando no se puede realizar pruebas de comportamiento, o cuando su ejecución es poco práctica.

Palabras clave: pérdida de audición • umbral de audición • CAEP • HEARLab • CTE

\section{ПРОТОКОЛ НЕАRLAВСОRTICAL TONE EVALUATION (CTE): ИССЛЕДОВАНИЕ КЛИНИЧЕСКОЙ ПРИГОДНОСТИ}

\section{Изложение}

Введение: В протоколах исследований наблюдается высокая корреляция корковых слуховых потенциалов с порогами тональной аудиометрии. Однако кроме центров, зависимых от NationalAcoustic Laboratories, дело касается ограниченной практики употребления системы HEARLab, использующей оценку с помощью процедуры corticaltoneevaluation (CTE). В настоящей работе показана возможность клинического применения протокола СТЕ с использованием системы HEARLab для оценки порогов тональной аудиометрии для частот 500, 1000, 2000 и 4000 Гц.

Материал и методы: В настоящем предварительном проспективном исследовании были сравнены пороги тональной аудиометрии с порогами воздушной проводимости, измеряемыми методом СТЕ, у 12 взрослых (в том числе у 8 с правильным слухом и у 4 с нейросенсорной тугоухостью). Протокол оценки порога корковых слуховых потенциалов создан на основании протокола для оценки слуховых стволомозговых ответов (ABR). Затем был проведен t-тест Стьюдента, чтобы указать разницу между порогами, получаемыми в бехавиоральном исследовании и СТЕ.

Результаты: Пороги СТЕ отличались от порогов тональной аудиометрии максимально на 11.2дБ. Среднее время проведения исследования для одного уха у всех 12 участников исследования составило 50.85 минут $(\mathrm{SD}=12,0)$. Были обсуждены также выводы, касающиеся повторяемости результатов между тестами для протокола СТЕ.

Выводы: Протокол СТЕ позволяет оценить пороги тональной аудиометрии как у людей с правильным слухом, так и у людей с нейросенсорной потерей слуха. Протокол СТЕ представляет собой альтернативу для тональной аудиометрии в случае, когда нельзя провести бехавиоральное исследование или когда его проведение является непрактическим.

Ключевые слова: потеря слуха • порог слышания • CAEP • HEARLab • CTE

\section{PROTOKÓŁ HEARLAB CORTICAL TONE EVALUATION (CTE): BADANIE PRZYDATNOŚCI KLINICZNEJ}

\section{Streszczenie}

Wprowadzenie: W protokołach badań obserwuje się wysoką korelację słuchowych potencjałów korowych z progami audiometrii tonalnej. Niemniej jednak, poza ośrodkami zależnymi od National Acoustic Laboratories, mamy do czynienia z ograniczoną praktyką użycia systemu HEARLab, wykorzystującego ocenę za pomocą procedury cortical tone evaluation (CTE). W niniejszej pracy zaprezentowano możliwości klinicznego zastosowania protokołu CTE z wykorzystaniem systemu HEARLab do estymacji progów audiometrii tonalnej dla częstotliwości 500, 1000, 2000 oraz 4000Hz.

Materiał i metody: W niniejszym, wstępnym badaniu prospektywnym, porównano progi audiometrii tonalnej z progami przewodnictwa powietrznego mierzonymi metodą CTE u 12 osób dorosłych (w tym 8 ze słuchem prawidłowym oraz $4 \mathrm{z}$ niedosłuchem odbiorczym). Protokół oceny progu słuchowych potencjałów korowych stworzono na podstawie protokołu do oceny odpowiedzi słuchowych z pnia mózgu (ABR). Następnie wykonano test t-Studenta celem wskazania różnic między progami uzyskiwanymi w badaniu behawioralnym oraz CTE.

Wyniki: Progi CTE różniły się od progów audiometrii tonalnej maksymalnie o 11,2 dB. Średni czas wykonania badania dla jednego ucha u wszystkich 12 uczestników badania, wynosił 50,85 minut $(\mathrm{SD}=12,0)$. Omówiono również wnioski dotyczące powtarzalności wyników między testami dla protokołu CTE.

Wnioski: Protokół CTE pozwala na estymację progów audiometrii tonalnej zarówno u osób z prawidłowym słuchem, jak i osób z odbiorczym ubytkiem słuchu. Protokół CTE stanowi alternatywę dla audiometrii tonalnej w przypadku, gdy badania behawioralnego nie można przeprowadzić, lub jeśli jego wykonanie jest niepraktyczne.

Słowa kluczowe: ubytek słuchu • próg słyszenia • CAEP • HEARLab • CTE

(C) Journal of Hearing Science ${ }^{\circledR} \cdot 2016$ Vol. 6 · No. 3 


\section{Introduction}

Electrophysiological measurements such as cortical auditory evoked potentials (CAEPs) provide an objective way to estimate behavioral hearing thresholds, and have been used since the 1960s and 70s. The reliability of any such test - its ability to produce stable and consistent behavioral hearing thresholds - is critical for diagnosis of hearing loss and optimizing intervention strategies. CAEPs have advantages over other electrophysiological measures, such as auditory brainstem responses (ABRs) and auditory steady-state responses (ASSRs). First, the CAEP is a measure of cortical function, whereas the ABR and high modulation ASSR only provide information at the brainstem $[1,2]$. Second, the amplitude of CAEPs is larger than the ABR and ASSR by about 5 to $10 \mu \mathrm{V}$ because CAEPs occur closer to the electrodes [3]. Finally, CAEPs correlate better with behavioral hearing thresholds than ABRs and ASSRs [4,5]

When reliable responses during pure tone audiometry cannot be obtained, the CAEP can be used as an objective estimator of the auditory threshold in adult patients [6,7]. Furthermore, CAEPs can be recorded in adults and children with hearing loss while they continue to wear their hearing aids $[8,9]$. Although CAEPs technique has a long history of empirical study in adult and pediatric populations, for several reasons it has not, unlike ABR and ASSR, been used routinely in the clinic for threshold estimation. The most significant clinical limitation is that CAEP does not fully mature until the late teens [10-12], meaning that, from birth to adolescence, the response pattern depends on the developmental stage. Although the response is not reliable at immature stages, it can still provide useful clinical information. The CAEP is affected by the patient's state of arousal, so drowsiness and sleep can affect the responses [13]. The CAEP latency, amplitude, and morphology can vary across age, individuals, and even from time to time within the same person [1] Other drawbacks include the long time that CAEPs take with standard evoked potential software [4], the high cost of equipment [14], and the absence of a user-friendly system designed for routine clinical practice; all have hindered the regular use of CAEPs [15]. Therefore, researchers have only considered CAEP for threshold estimation in older children and adults [16].

The HEARLab system is promising in terms of being a user-friendly system which can save testing time. The HEAR$\mathrm{Lab}^{\star}$ system is manufactured by Frye Electronics, Inc. under license from HEARworks Pty Ltd, the commercialization arm of the HEARing Cooperative Research Centre (CRC) in Australia. It was developed by the HEARLab Research Team at the National Acoustics Laboratories (NAL). The HEARLab system offers an innovative objective approach using scalp-recorded CAEPs to estimate behavioral hearing thresholds. A built-in, automated statistical response detection algorithm (Hotelling's $T^{2}$ ) is used to provide threshold estimates from CAEPs using a $p$-value of $<0.05$ to determine the reliability of a response, which means there is only a $5 \%$ chance that HEARLab will record a false-positive response [17]. The automated detection paradigm is designed to enhance the clinician's confidence as to the presence or absence of a CAEP, an important consideration in the light of the variability of CAEPs between and within subjects.

Although CAEPs have, when using research protocols, been shown to demonstrate high correlations with behavioral hearing thresholds $[7,18,19]$, clinical experience using the HEARLab procedures at sites independent of NAL remains limited. Following approval of the HEARLab system in April 2013 by the U.S. Food and Drug Administration (FDA), we sought to assess whether, in a clinical setting, HEARLab was feasible (or practical) for determining behavioral hearing thresholds and was suitable for further testing and future use.

\section{Material and methods}

This primary prospective study of adults with normal hearing or hearing loss was reviewed and approved by the University of Arkansas for Medical Sciences (UAMS) Institutional Review Board (IRB), Protocol \#202588. All participants were informed about the study and gave written consent.

\section{Participants}

Participants were 12 adult volunteers aged 20 years or older (mean 30.55 yr; SD 14.3 yr; range 20-63 yr) with normal hearing (Group 1: 8 participants) or sensorineural hearing loss (SNHL; Group 2: 4 participants). Inclusion criteria for the normal hearing group $(n=8)$ was pure-tone threshold $\leq 20 \mathrm{~dB} H \mathrm{HL}$ at each of the frequencies 500,1000, 2000, and $4000 \mathrm{~Hz}$; for the hearing loss group $(n=4)$ the criterion was $>20 \mathrm{~dB} H \mathrm{HL}$ at the same four frequencies. Participants with cochlear implants were excluded from the study. Table 1 lists the participants by gender, age, and hearing status.

\section{Equipment}

All data was collected in a double-walled IAC acoustic booth. Two pieces of equipment were used for measuring behavioral hearing thresholds and CAEPs: (a) a Grason-Stadler (GSI) AudioStar Pro audiometer (Eden Prairie, MN) [20], and (b) the HEARLab system [17].

The HEARLab system has two assessments: aided cortical assessment (ACA) and cortical tone evaluation (CTE) [17]. The ACA is used to obtain objective information about a patient's response to sounds heard through hearing aids. The ACA is capable of recording CAEPs in response to three natural speech sounds, $/ \mathrm{m} /, / \mathrm{g} /$, and $/ \mathrm{t} /$, with low, mid, and high frequency emphasis respectively. Responses to all three sounds provide reassurance that a patient is able to detect sounds across the range of speech frequencies. In contrast, the CTE procedure generates stimuli which are used to evoke and record CAEPs responses, allowing behavioral hearing threshold at 500, 1000, 1500, 2000, 3000, and $4000 \mathrm{~Hz}$ to be estimated. Both the ACA and CTE techniques have the potential to test adults and children who are unable to undergo a standard behavioral hearing evaluation [17]. The CTE module was used in the current study.

\section{Procedures}

Preliminary procedures included set-up, calibration, and training to ensure familiarity with the HEARLab system 
Table 1. Participants' gender, age, and hearing status

\begin{tabular}{cccc}
\hline Subject & Gender & Age (years; months) & PT Threshold \\
\hline 1 & $F$ & $21 ; 2$ & Normal \\
\hline 2 & $M$ & $21 ; 2$ & Normal \\
\hline 3 & $M$ & $23 ; 6$ & Normal \\
\hline 4 & $F$ & $23 ; 11$ & Normal \\
\hline 5 & $M$ & $24 ; 8$ & Normal \\
\hline 6 & $F$ & $24 ; 9$ & Normal \\
\hline 7 & $F$ & $25 ; 1$ & Normal \\
\hline 8 & $M$ & $28 ; 7$ & Hearing loss \\
\hline 9 & $F$ & $20 ; 0$ & Hearing loss \\
\hline 10 & $F$ & $34 ; 10$ & Hearing loss \\
\hline 11 & M & $57 ; 8$ & Hearing loss \\
\hline
\end{tabular}

Hearing status based on pure-tone thresholds at 500, 1000, 2000, $4000 \mathrm{~Hz}$. Normal hearing: $\leq 20 \mathrm{~dB} \mathrm{HL}$ at each frequency. Hearing loss: $>20 \mathrm{~dB}$ HL at each frequency. $\mathrm{M}$ - male; F - female; PT - pure-tone.

Table 2. The HEARLab clinical CTE protocol

\footnotetext{
1. Select and record frequency order and test ear selected on the data form.

a. Base test frequency order and test ear selection on predetermined Latin Square table assignments (i.e., 500, 1000, 2000, and $4000 \mathrm{~Hz}$; left ear or right ear).

b. Apply electrodes using the following montage: vertex (Cz) - non-inverting; mastoid of test ear (M1 or M2) - reference; mastoid of non-test ear (M1 or M2) - ground. Apply vertex electrode halfway between two ears and halfway between nasion and inion. c. Present stimulus at $60 \mathrm{~dB} \mathrm{HL}$ at the first frequency. If present, proceed to \#3.

2. If absent/abnormal:

a. Complete listening check to rule out equipment malfunction.

b. If waveform is a completely flat line and the listening check is good, proceed with threshold-seeking procedure by increasing the intensity in 20 to $40 \mathrm{~dB}$ increments as deemed appropriate on a case-by-case basis.

c. If a response is obtained, proceed to \#3.
}

3. Proceed with frequency-specific data collection by decreasing in $20 \mathrm{~dB}$ step size until no response is detected.

4. Increase in $10 \mathrm{~dB}$ increments until a response is obtained, decrease by $5 \mathrm{~dB}$ and record estimated threshold (lowest level at which $\mathrm{p}<0.05)$.

5. Repeat process at remaining octave frequencies and record test time, threshold estimates, and other data.

6. Note any protocol deviations on data collection form.

and protocol. All participants underwent the same evaluation protocol as follows. Pure tone thresholds (termed PT thresholds in this study) were collected at four frequencies $(500,1000,2000$, and $4000 \mathrm{~Hz})$ via an ER-3A insert earphone using the standard behavioral threshold method and a hand-raising response [21]. In preparation for the CTE, participants sat upright in a chair (not reclined) and snap-on, gel-filled disposable adhesive electrodes were applied using the following montage: $\mathrm{Cz}$, non-inverting; ipsilateral M1 or M2, inverting; and contralateral M1 or M2, ground. Electrode connections were checked before a test, and if necessary the preparation was repeated to achieve electrode impedance values $<5 \mathrm{k} \Omega$. The HEARLab system was set to allow up to 200 artifact-free epochs, but a run may have less epochs if all other conditions were met (i.e., noise is satisfactory and $p$-level reached). Participants were instructed that assessment was automatic and there was no need to actively listen or respond to the stimuli). Participants were given the option to read a book or magazine or just relax (i.e., remain quiet but awake) during a test. The CTE was performed at 500, 1000, 2000, and $4000 \mathrm{~Hz}$, with the sound stimuli presented through an insert earphone to just one ear of each subject. The ear to be tested was alternated between subjects. The order of the test frequencies for both the behavioral and the electrophysiological procedures were counterbalanced using a Latin Square to control for sequencing effects [21]. The impedance of electrodes was checked to make sure it did not exceed $5 \mathrm{k} \Omega$. The CTE data were stored on the HEARLab unit and also recorded on a data collection form. The overall test time to collect CTE thresholds at all four frequencies per ear was recorded. The CTE protocol used in the current study was modeled after an existing ABR protocol used in-house (Table 2). 
Table 3. Means and standard deviations of PT and CTE thresholds

\begin{tabular}{|c|c|c|c|c|c|}
\hline \multirow{4}{*}{$\begin{array}{c}\text { Frequency } \\
500 \mathrm{~Hz}\end{array}$} & \multirow{3}{*}{$\begin{array}{c}\begin{array}{c}\text { Group } \\
(\mathbf{1 = n o r m a l} \text { hearing, } \\
\mathbf{2}=\text { hearing loss) }\end{array} \\
1(n=8)\end{array}$} & \multirow{2}{*}{\multicolumn{2}{|c|}{$\begin{array}{c}\text { PT threshold } \\
\text { Mean (SD) }\end{array}$}} & \multirow{2}{*}{\multicolumn{2}{|c|}{$\begin{array}{c}\text { CTE threshold } \\
\text { Mean (SD) }\end{array}$}} \\
\hline & & & & & \\
\hline & & 13.02 & $(5.70)$ & 18.00 & (9.10) \\
\hline & $2(n=4)$ & 48.75 & (15.50) & 41.25 & (19.31) \\
\hline \multirow{2}{*}{$1000 \mathrm{~Hz}$} & $1(n=8)$ & 13.00 & $(6.71)$ & 16.00 & $(7.42)$ \\
\hline & $2(n=4)$ & 61.25 & (23.94) & 50.00 & (26.46) \\
\hline \multirow{2}{*}{$2000 \mathrm{~Hz}$} & $1(n=8)$ & 9.00 & $(4.18)$ & 10.00 & (13.70) \\
\hline & $2(n=4)$ & 67.50 & (22.17) & 56.25 & $(25.62)$ \\
\hline \multirow{2}{*}{$4000 \mathrm{~Hz}$} & $1(n=8)$ & 7.00 & $(2.74)$ & 12.00 & (17.00) \\
\hline & $2(n=4)$ & 72.50 & $(26.30)$ & 71.25 & (22.90) \\
\hline
\end{tabular}

PT - pure-tone; SD - standard deviation; $n$ - sample size.

Table 4. Run times at CTE threshold and number of accepted and rejected epochs

\begin{tabular}{|c|c|c|c|c|c|c|c|}
\hline \multirow[t]{2}{*}{ Frequency } & \multirow{2}{*}{$\begin{array}{c}\text { Group } \\
\text { (1=normal hearing, } \\
2=\text { hearing loss) }\end{array}$} & \multirow{2}{*}{\multicolumn{2}{|c|}{$\begin{array}{c}\text { Time at CTE threshold } \\
\text { (minutes) } \\
\text { Mean (SD) }\end{array}$}} & \multirow{2}{*}{\multicolumn{2}{|c|}{$\begin{array}{c}\text { Accept epochs } \\
\text { Mean (SD) }\end{array}$}} & \multirow{2}{*}{\multicolumn{2}{|c|}{$\begin{array}{c}\text { Reject epochs } \\
\text { Mean (SD) }\end{array}$}} \\
\hline & & & & & & & \\
\hline \multirow{2}{*}{$500 \mathrm{~Hz}$} & $1(n=8)$ & 3.0 & (1.10) & 132.0 & (58.10) & 2.2 & $(0.45)$ \\
\hline & $2(n=4)$ & 2.0 & (1.15) & 89.5 & (51.63) & 2.0 & $(0.00)$ \\
\hline \multirow{2}{*}{$1000 \mathrm{~Hz}$} & $1(n=8)$ & 2.0 & $(0.71)$ & 100.0 & $(37.01)$ & 2.2 & $(0.04)$ \\
\hline & $2(n=4)$ & 2.0 & (1.41) & 98.0 & $(67.70)$ & 2.25 & $(0.50)$ \\
\hline \multirow{2}{*}{$2000 \mathrm{~Hz}$} & $1(n=8)$ & 2.0 & (1.34) & 71.0 & $(68.85)$ & 2.8 & (1.30) \\
\hline & $2(n=4)$ & 2.0 & $(0.50)$ & 87.5 & (43.43) & 2.25 & $(0.50)$ \\
\hline \multirow{2}{*}{$4000 \mathrm{~Hz}$} & $1(n=8)$ & 2.0 & $(0.71)$ & 98.0 & (51.80) & 3.0 & $(1.41)$ \\
\hline & $2(n=4)$ & 1.5 & $(0.57)$ & 63.0 & (19.00) & 2.25 & $(0.50)$ \\
\hline
\end{tabular}

Statistical analysis

Statistical Package for the Social Sciences v.20 software was used to analyze data using descriptive and inferential statistics. To identify the decibel differences between PT and CTE thresholds in Group 1 (normal hearing) and in Group 2 (SNHL), $t$-tests were used, with $p \leq 0.05$ being the criterion for significance. A Bonferroni correction was used because several independent statistical tests were being performed simultaneously on each group data set.

\section{Results}

Data from 12 participants were included in the data analysis. To summarize the PT and CTE thresholds for Group 1 and Group 2, descriptive statistics (i.e., means and standard deviations) were computed and the results are shown in Table 3. The run times at CTE threshold, and the number of accepted and rejected epochs, were calculated at four frequencies in both groups, and the results are shown in Table 4. As an example, Figure 1 shows CTE responses for a participant with normal hearing at $500 \mathrm{~Hz}$.
Group 1 - normal hearing

Table 3 shows that the PT threshold of all 8 participants at all four frequencies was within normal limits ( $\leq 20 \mathrm{~dB} H \mathrm{HL})$. However, the mean CTE threshold at each frequency was found to be at a higher intensity than the mean PT threshold, with more variation (SD) seen at 2000 and $4000 \mathrm{~Hz}$. As shown in Figure 2 and Table 3, the disagreement between mean PT and CTE thresholds was $\pm 5 \mathrm{~dB}$ at all four frequencies, and in fact there was no significant difference between the PT and CTE thresholds [ $t(7)=-0.50, p>0.35]$. As Table 4 shows, the CTE threshold at $500 \mathrm{~Hz}$ had the longest test time and required more accepted epochs to reach a probability less than 0.05 compared to other frequencies (using Hotelling's $T^{2}$ formula). The mean total $\mathrm{CTE}$ test time was 50 minutes $(\mathrm{SD}=14)$.

Group 2 - hearing loss

All 4 participants had individual frequency thresholds ranging from $25 \mathrm{~dB}$ to $100 \mathrm{~dB}$ HL. The mean disagreement between PT and CTE thresholds was $\pm 11.2 \mathrm{~dB}$ (see Table 4 and Figure 3). Statistically, there was no significant 


\begin{tabular}{|c|c|c|c|c|}
\hline dB HL & $p$ value & P1 (ms) & $\mathrm{N} 1$ (ms) & P2 (ms) \\
\hline \multicolumn{5}{|l|}{110} \\
\hline \multicolumn{5}{|l|}{105} \\
\hline \multicolumn{5}{|l|}{100} \\
\hline \multicolumn{5}{|l|}{95} \\
\hline \multicolumn{5}{|l|}{90} \\
\hline \multicolumn{5}{|l|}{85} \\
\hline \multicolumn{5}{|l|}{80} \\
\hline \multicolumn{5}{|l|}{75} \\
\hline \multicolumn{5}{|l|}{70} \\
\hline \multicolumn{5}{|l|}{65} \\
\hline 60 & 0.00 & 38 & 100 & 191 \\
\hline \multicolumn{5}{|l|}{55} \\
\hline \multicolumn{5}{|l|}{50} \\
\hline \multicolumn{5}{|l|}{45} \\
\hline \multicolumn{5}{|l|}{40} \\
\hline \multicolumn{5}{|l|}{35} \\
\hline \multicolumn{5}{|l|}{30} \\
\hline \multicolumn{5}{|l|}{25} \\
\hline 20 & 0.01 & 57 & 116 & 210 \\
\hline \multicolumn{5}{|l|}{15} \\
\hline 10 & 0.03 & 79 & 144 & 233 \\
\hline 5 & 0.72 & & & \\
\hline 0 & 0.43 & & & \\
\hline \multicolumn{5}{|l|}{-5} \\
\hline-10 & & & & \\
\hline
\end{tabular}

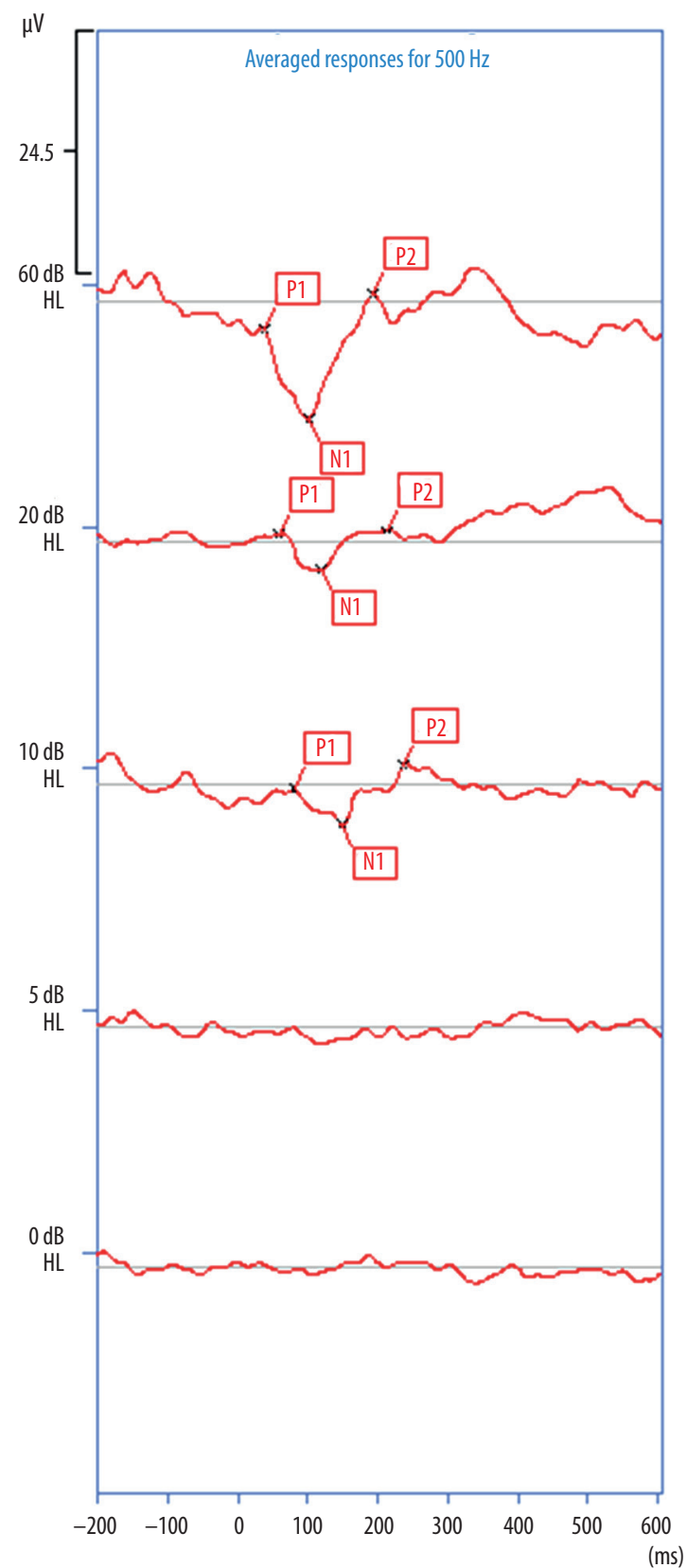

Figure 1. Example, recorded at $500 \mathrm{~Hz}$, of CTE averaged responses, statistical results, and marked latencies for a participant with normal hearing thresholds at $500 \mathrm{~Hz}$

difference between PT and CTE thresholds $[t(3)=2.83$, $p>0.27]$. CTE at $500 \mathrm{~Hz}$ had the longest test time and needed more accepted epochs to reach a probability of 0.05 compared to other frequencies. The mean CTE time across frequencies was 52.75 minutes $(\mathrm{SD}=11.32)$.

\section{Discussion}

This study set out to assess the clinical feasibility of using the HEARLab system to estimate the PT thresholds of adults with normal hearing or hearing loss at four frequencies. To reduce test time we chose to assess the CTE at only four frequencies, 500, 1000, 2000, and $4000 \mathrm{~Hz}$, and in just one ear of each subject. Because there are no significant differences between the cerebral hemispheres, recording CAEPs from one ear or the other should make no difference [1].

\section{Agreement of PT and CTE thresholds}

Our findings suggest that PT thresholds can be accurately predicted by the CTE procedure. Previous research has shown that CAEP measures are in good agreement (i.e., $\pm 10 \mathrm{~dB}$ ) with PT thresholds in most cases $[6,7,18]$. Picton (2011) reported that CAEPs were on average about $10 \mathrm{~dB}$ higher than PT thresholds [22]. Other researchers 


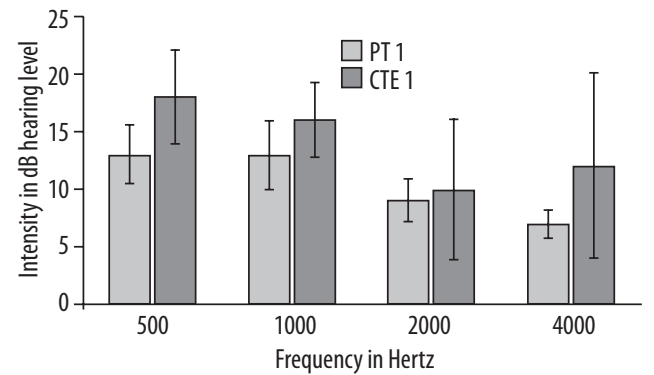

Figure 2. Mean pure-tone and CTE thresholds of Group 1 (normal hearing). Error bars show standard deviations. PT - pure-tone threshold; CTE - cortical tone evaluation

have found differences of $>15 \mathrm{~dB}$ between PT and cortical thresholds. Albera et al. (1991) found that in some cases there was a gap of $>20 \mathrm{~dB}$ between PT threshold and CAEP [23]. Van Dun et al. (2015) found that in three participants $4 \%$ of CAEP thresholds were $>30 \mathrm{~dB}$ above their PT thresholds [19]. In the current study, the mean difference between PT threshold and CTE threshold in Group 1 (normal hearing) was $\pm 5 \mathrm{~dB}$ (the CTE overestimated the PT threshold). Lightfoot and Kennedy (2006) studied 24 adults with normal hearing and found a mean difference of $6.5 \mathrm{~dB}$ between PT and cortical thresholds and, after correction, $94 \%$ of threshold estimates had mean differences of $\leq 15 \mathrm{~dB}$ [4]. Among $80 \%$ of the participants, mean differences were estimated as $\leq 10 \mathrm{~dB}$. Durante et al. (2016) evaluated 31 adults with normal hearing and 21 adults with SNHL [1]; they reported a mean difference of 14.5 $\mathrm{dB}$ between behavioral and cortical thresholds in the normal hearing group.

In Group 2, the hearing loss group, our study showed that the mean difference between both thresholds was \pm 11.2 $\mathrm{dB}$ (the CTE underestimated the PT threshold). Van Dun et al. (2015) evaluated CAEP thresholds in 34 adults with hearing loss and found that the average cortical threshold assessment was $10 \mathrm{~dB}$ higher than the PT threshold [19]. Durante et al. (2016) found a mean difference of $7.8 \mathrm{~dB}$ between both thresholds among 21 adults with SNHL [1]. Yueng and Wong (2007) investigated the cortical thresholds among 34 adults with normal hearing or mild to profound SNHL [5]. The differences between PT and cortical thresholds were mostly within $5 \mathrm{~dB}$ and not more than $10 \mathrm{~dB}$. The CTE threshold might be better than expected for individuals with SNHL due to the potential impact of loudness recruitment, which would increase more rapidly and make the detection of threshold at fewer epochs to reach $p<0.05[24,25]$. Therefore, the mean difference between PT and CTE thresholds for those with SNHL could be smaller than the difference for those with normal hearing. In summary, good agreement between both PT and CTE thresholds for individuals with normal hearing and with SNHL was found.

\section{CTE protocol}

Our protocol showed the mean CTE test-time for each ear at the four frequencies among all participants was $50 \mathrm{~min}$ utes in Group 1 and 52.75 minutes in Group 2. In Group 1, the average time to reach CTE threshold was 9.0 minutes

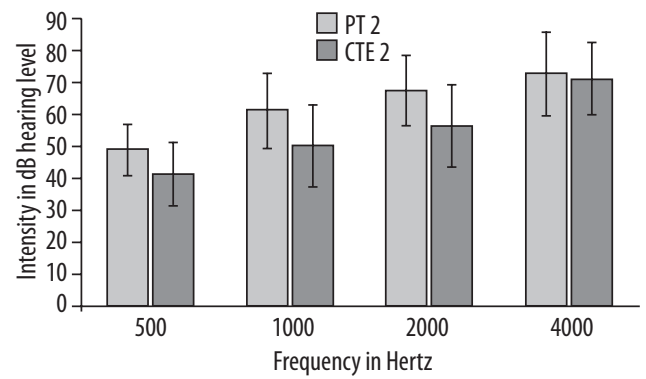

Figure 3. Mean pure-tone and CTE thresholds of Group 2 (hearing loss). Key as per Figure 2

(3.0 minutes at $500 \mathrm{~Hz}, 2.0$ minutes at 1000, 2000, and $4000 \mathrm{~Hz}$ ), whereas in Group 2 the average time to reach CTE threshold was 7.25 minutes (2.0 minutes at 500, 1000, and $2000 \mathrm{~Hz}$, and 1.5 minutes at $4000 \mathrm{~Hz}$ ). The protocol used in this study led to prolonged CTE times, which is not appropriate for routine use if assessment of CTE threshold is needed for both ears. That said, the average time to reach CTE threshold in both groups was consistent with other studies aimed at measuring cortical responses. Van Maanen and Stapells (2005) reported an average of 14.9 minutes to measure four cortical evoked response audiometry thresholds in one ear, and 22 minutes to measure three frequencies in both ears [26]. A protocol by Lightfoot and Kennedy (2006) took 20.6 minutes to measure three cortical thresholds bilaterally [4]. In summary, our study revealed that CTE can be time-efficient if an appropriately designed test protocol is used.

\section{Clinical applications}

There are advantages in using the HEARLab CTE procedure for hearing threshold estimation. HEARLab uses an automated statistical detection method (Hotelling's $T^{2}$ ), so variation due to examiner experience in interpreting waveform morphology is minimized. This automatic statistical detection has been previously proven capable of detecting CAEPs with equal or greater sensitivity to that achieved by expert clinicians $[2,24]$. In our experience, we found the automation quite helpful to examine and detect all responses. In particular, the noise detection feature and probability graph were especially helpful for increasing user confidence. Additionally, while the CTE procedure assesses the integrity of the auditory pathway from the auditory canal to the cortex, cortical responses may also be useful in some cases of auditory neuropathy spectrum disorder (ANSD) [27]. Children with ANSD are another clinical population of interest. Shuman et al. (2013) found that PT and CAEP thresholds were within 5-10 dB of each other at 500 and $2000 \mathrm{~Hz}$; at other frequencies CAEPs were higher by $20-25 \mathrm{~dB}$ at $250 \mathrm{~Hz}$ and 10-15 dB higher at $4000 \mathrm{~Hz}$ [28]. ABR results alone may be misleading in cases of ANSD [29].

CTEs can be reliably recorded in awake adults and children with normal hearing and with hearing loss, thereby eliminating the requirement for the patient to be asleep and the risks associated with sedation. We found that the detected cortical threshold by CTE was within $11.2 \mathrm{~dB}$ of 
PT threshold, a result similar to other electrophysiological techniques. HEARLab is a frequency-specific, singlechannel recording system, which is well suited to detect CAEPs. Furthermore, the three electrodes that are included with HEARLab system are colored and clearly labeled on the electrode and the electrode processor to make attaching electrodes, and maintaining placement during testing, easy. The software is easy to use. Test stimuli can be presented using either air or bone conduction transducers (i.e., insert earphones or a bone oscillator). However, bone conduction is not routinely used for cortical responses [30]. Development of a protocol that minimizes the threshold estimation time, particularly if bilateral cortical thresholds are needed, would dramatically increase the potential of CTE as a routine clinical measure, particularly as it increases the chances of participant compliance and better outcomes. Finally, results of this study support the idea that CTE warrants attention and additional research; it is a potential contributor and 'cross check' for pediatric patients or those with developmental delays.

\section{Limitations}

There are limitations to this study. The number of participants, while about the same as in a few prior studies, is small, and therefore interpretation of the results should be taken with caution and overgeneralization of the data avoided. There was no control for the participants' age, gender, or degree of hearing loss. The study sample comprised only adult subjects who remained still throughout the procedure and were cooperative, aspects which can often be challenging when working with pediatric subjects. Strategies to further engage children will need to be developed and evaluated prior to routine application with this age group. The role of the clinician in keeping the child engaged is critical; they also need to monitor responses carefully so that threshold detection is as fast as possible.

\section{Conclusions}

This study contributes to a growing body of literature on clinical equipment that has recently received FDA approval. The CTE HEARLab procedure appears to be feasible to predict PT thresholds and useful as an alternative tool when PT threshold testing is neither possible nor practical. Further studies with HEARLab are needed with a larger sample size, different age groups, and other test protocols to refine the model, test-time, and accuracy.

\section{Acknowledgments}

The authors thank all participants for their time and cooperation. This study was funded in part by the McNiece Doctoral Research Fellowship Award, University of Central Arkansas Foundation.

\section{Conflict of interests}

The authors declare no potential conflict of interests.

\section{References:}

1. Durnate AS, Wieselberg MB, Roque N, Carvalho S, Pucci B, Gudayol N, de Almeida K. Assessment of hearing threshold in adults with hearing loss using an automated system of cortical auditory evoked potential detection. Braz J Otorhinolaryngol, 2016; 16: 1-8

2. Hall, JW. New Handbook of Auditory Evoked Responses. Boston, MA: Pearson, Allyn and Bacon; 2007.

3. Dillon H. So, baby, how does it sound? Cortical assessment of infants with hearing loss. Hearing Journal, 2005; 58(10): 10-17.

4. Lightfoot G, Kennedy V. Cortical electric response audiometry hearing threshold estimation: Accuracy, speed, and the effects of stimulus presentation features. Ear Hear, 2006; 27(5): 443-56.

5. Yeung KNK, Wong LLN. Prediction of hearing thresholds: Comparison of cortical evoked response audiometry and auditory steady state response audiometry techniques. Int J Audiol, 2007; 46: 17-25.

6. Hyde M. The N1 response and its applications. Audiol Neurotol, 1997; 2: 281-307.

7. Tus B, Wong LLN, Wong ECM. Accuracy of cortical evoked response audiometry in the identification of non-organic hearing loss. Int J Audiol, 2002; 41: 330-33.

8. Billings CJ, Tremblay KL, Miller CW. Aided cortical auditory evoked potentials in response to changes in hearing aid gain. Int J Audiol, 2011; 50(7): 459-67.

9. Carter L, Dillon H, Seymour J, Seeto M, Van Dun B. Cortical auditory-evoked potentials (CAEPs) in adults in response to filtered speech stimuli. J Am Acad Audiol, 2013; 24: 807-22.
10. Sharma A, Dorman MF, Spahr AJ. A sensitive period for the development of the central auditory system in children with cochlear implants: Implications for age of implantation. Ear Hear, 2002; 23(6): 532-39.

11. Wunderlich JL, Cone-Wesson BK, Shepherd R. Maturation of the cortical auditory evoked potential in infants and young children. Hear Res, 2006; 212(1-2): 185-202.

12. Sussman E, Steinschneider M, Gumenyuk V, Grushko J, Lawson $\mathrm{K}$. The maturation of human evoked brain potentials to sounds presented at different stimulus rates. Hear Res, 2008; 236(1-2): 61-79.

13. Crowley KE, Colrain IM. A review of the evidence for P2 being an independent component process: Age, sleep and modality. Clin Neurophysiol, 2004; 115(4): 732-44.

14. Golding M, Dillon H, Seymour J, Carter L. The detection of adult cortical auditory evoked potentials (CAEPs) using an automated statistic and visual detection. Int J Audiol, 2009; 48(12): 833-42.

15. Atcherson SR, Gould HJ, Pousson MA, Prout TM. Long-term stability of N1 generators using low-resolution electromagnetic tomography. Brain Topogr, 2006; 19: 11-20.

16. Martin B, Tremblay KL, Stapells, DR. Principles and applications of cortical auditory evoked potentials. In: Burkard R, Don M, Eggermont JJ, editors. Auditory Evoked Potentials: Basic principles and applications. Lippincott: Williams \& Wilkins; 2007; 497-507.

17. HEARLab System. Operator's manual 2015. Retrieved from http://www.frye.com/wp/wp-content/uploads/2013b/manuals/ hearlab.pdf. 
18. Prasher D, Mula M, Luxon L. Cortical evoked potential criteria in the objective assessment of auditory threshold: A comparison of noise induced hearing loss with Meniere's disease. J Laryngol Otol, 1993; 107: 780-86.

19. Van Dun B, Dillon H, Seeto M. Estimating hearing thresholds in hearing-impaired adults through objective detection of cortical auditory evoked potentials. J Am Acad Audiol, 2015; 26: $370-83$.

20. Grayson-Stadler: GSI AudioStar Pro. Two-channel clinical au-

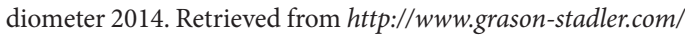
products/gsi-audiostar.

21. American Speech-Language-Hearing Association (ASHA). Guidelines for Manual Pure-Tone Threshold Audiometry 2004. Retrieved from http://www.asha.org/policy/GL2005-00014/.

22. Picton TW. Human Auditory Evoked Potentials. San Diego, CA: Plural Publishing Inc.; 2011.

23. Albera R, Canal, G, Magnano M, Lacilla, M, Morra B, Rugiu MG, Cortesina G. Relations between pure-tone audiometry and cortical evoked auditory potentials. Acta Otorhinolaryngol Ital, 1991; 11: 551-62.

24. Carter L, Golding M, Dillon H, Seymour J. The detection of infant cortical auditory evoked potentials (CAEPs) using statistical and visual detection techniques. J Am Acad Audiol, 2010; $21: 347-56$.
25. Munro KJ, Purdy SC, Ahmed S, Begum R, Dillon H. Obligatory cortical auditory evoked potential waveform detection and differentiation using a commercially available clinical system: HEARLab. Ear Hear, 2011; 32: 782-86.

26. Van Maanen A, Stapells DR. Comparison of multiple auditory steady-state responses ( 80 versus $40 \mathrm{~Hz}$ ) and slow cortical potentials for threshold estimation in hearing-impaired adults. Int J Audiol, 2005; 44(11): 613-24.

27. Pearce W, Golding M, Dillon H. Cortical auditory evoked potentials in the assessment of auditory neuropathy. J Am Acad Audiol, 2007; 18(5): 380-89.

28. Shuman H, Teagle HF, Rouch P, Grose J, Buchman C. Objective hearing threshold estimation in children with auditory neuropathy spectrum disorder. Laryngoscope, 2013; 123: 2859-61.

29. Narne VK, Vanaja C. Speech identification and cortical potentials in individuals with auditory neuropathy. Behav Brain Funct, 2008; 31: 4-15.

30. Durrant JD, Hyre R. Relative effective frequency response in bone versus air conduction stimulation examined via masking. Audiol J, 1993; 32: 175-184. 